\title{
newly developed techniques \\ of enzyme-labelled antibody method
}

酵素抗体法の最新技術

part II

Hiroshi Nagura*,

名倉 宏*, 長谷川英章・小松遵至**

Hideaki Hasegawa $\cdot$ Noriyuki Komatsu**

\section{medical technology}

生体の構造機能, およびそれらの病的変化の検索も, 近年細胞内小器官レベルまで細分されて行われるように なり，種々の生物活性を有する物質の局在も電顕レベル で観察したいという要望が高まっている。

組織細胞が有する物質の局在を，直接抗原抗体反応を 利用して電顕レベルで観察を可能にしたのが，1959年 Singerにより考案されたところの抗体をフェリチンで標 識する方法（フェリチン抗体法）で，そのときまで，光 学顕微鏡レベルにとどまっていた免疫組織においても, 電子顕微鏡による観察が可能になった。しかし，フェリ チン一抗体複合物の分子が大きく細胞内の抗原局在観察 には必ずしも適さなかった。 その後, Nakane による酵 素標識抗体法 (enzyme labelled antibody method)の 創案により, 物質の細胞内小器官単位での局在観察がは じめて可能となり，その超微形態変化と物質組成や機能 変化との関連を, より詳細に解明することができるよら になった。

Nakane の酵素抗体法による光顕観察と, 電顕観察と の染色原理については，基本的にはまったく違いはな く，本稿の part I に述べたと拈りであり，それを参照 されたい。したがって，電顕レベルでの酵素標識抗体法

(以下電顕酵素抗体法) を行ら重要なポイントも,

(1) 特異性が高く, 力価もすぐれた抗体を用いること

(2) 抗原の厳密な不動化 (immobilization) と微細構 造の保持および抗原性の保存が可能な固定液の選択にあ るが，電顕酵素抗体法ではよりきびしい条件が要求され ることはいうまでもない.さらに，

(3) 電顕酵素抗体法では, 細胞内小器官レベルでの正 確な抗原局在を追求するがその最大の目的であるから， 標識抗体が小器官のすみずみまで満遍なく浸透し, 抗原 抗体反応が正しく行われることが必須である。

本稿では，この電顕酵素抗体法の手技の実際と，その 実施にあたって留意すべき点を述べ，あわせて筆者らの 研究室での種々の抗原物質の観察結果を供覧する.

* Department of Pathology and **Cell Biology Research Laboratory, Tokai University School of Medicine *東海大学医学部病理学教室, **同 共利研細胞生物部門

\section{電顕酵素抗体法の手技の実際}

(1) 組織の採取と固定操作

電顕酵素抗体法を用い，電子顕微鏡 で 組織細胞を観 察する目的は，第一に生体を構成する組織細胞ならびに 物質の局在を超微形態レベルでより正確にとらえるため であり，そのため，組織細胞構造を保存し， かつ検出 すべき抗原物質の移動や消失を極力小さくすることに細 心の注意を払うことが肝要である。すなわち，もっとも 理想的な固定とは “selective preservation of cell structures and components for subsequent study (Gorsh)" であり，さらに免疫組織化学の場合はできるだけその抗 原性を保存するといら条件も満足させなければならな い.この意味でも, 電顕酵素抗体法のよしあしは固定に より決まるといっても過言ではない.

現在なお，腎生検（図 8 ）などは多くの場合，末固定 の組織で免疫組織化学的観察が行われているが，こうし た観点からも一部の例外を除き厳につつしもべき観察法 といわざるをえない。また細胞や組織の構造あるいはそ こに存在している物質のなかで，なにを観察しようとし ているか, その目的に応じて組織採取法, 固定法打よび 固定液を選択しなければならない。それらの詳細につい ては, part I に述べたが，一般に McLean-Nakane の PLP (periodate-lysine-paraformaldehyde) ${ }^{1)}$ を用いるこ とにより良好な結果を得ている。

\section{（2）凍結切片作成}

固定操作につづく，固定液の洗浄と凍結ならびに凍結 切作成の操作は光顕用切片のそれと基本的に同じであ る. 最近, 凍結超薄切片法 ${ }^{2}$ が開発され, 直接凍結超薄 切片上で抗原抗体反応を施行することが可能となり, 電 顕酵素抗体法やフェリチン抗体法にとって，理想的な 方法と考えられるが, 凍結超薄切片作成装置が未完で, 高価な点と高度の技術を要することから，まだ一部の研 究者によって試みられているにすぎない. 樹脂包埋され た組織の超薄切片上で, 抗原抗体反応を行う樹脂超薄切 片法 (post-embedding method) ${ }^{3}$ については後述する.

（3）ペルオキシダーゼ標識抗体による抗原抗体反応 このステップの基本操作も, 光顕の場合と同じで, 大 別して抗原抗体反応を一段でおさ方る直接法と, 二段で 
行う間接法とがある。凍結切片法の場合, $6 \mu$ 切片上で 標識抗体を反応させた後, その切片から電顕用の超薄切 片を作成するので，その標識抗体が組織切片中に十分か つ満遍なく浸透し, 細胞内小器官を含めた細胞内で抗原 抗体反応が十分正しく行われている必要がある。そのた め, 反応時間は一次・二次抗体とも $2 \sim 12$ 時間を要す る.（反応時間が 6 時間を越觉る場合, 抗原性, ペルオ キシダーゼの酵素活性, ならびそ組織細胞の微細構造保

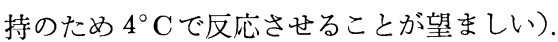

また，標識抗体の組織細胞内への浸透性をよくするた め，標識される抗体の $\operatorname{IgG}$ の分子を小さくすることが考 えられ, Mitani らは, IgGの $\mathrm{Fab}^{\prime}$ フラグメントにペ ルオキシダーゼを標識することにより，いままで免疫組 織化学的に検出不可能とされていたミトコンドリア内の 抗原蛋白の検出に成功している $\left(\right.$ 図10 ${ }^{4)}$. 間接法の場合 も, 一次抗体に検出すべき抗原に対する抗体の IgG の $\mathrm{Fab}^{\prime}$ フラグメントを用い，二次抗体として，一次抗体 を作成した動物の IgG の $\mathrm{Fab}^{\prime}$ に対する抗血清よりつ くったペルオキシダーゼ標識抗体 $\left(\mathrm{Fab}^{\prime}\right)$ を用い, 理想 的な結果を得ている ${ }^{5)}$. 表 1 は，用いた抗体の分子の大 きさと抗原物質を検出可能な小器官との関係々゙にたも のである.

近年, 標識抗体法の一つに Avidin-Biotii 法が用いら れはじめたが，この最大の利点は，Biotin はビタミン H で分子量が244と非常に小さく，抗体い $\mathrm{Fab}^{\prime}$ を用いた場 合, Biotin-酵素, Biotin-抗体, Ari'n のおのおのの分 子量が 7 万以上とならず，組織細"'内のあらゆる場所に 浸潤可能であり, 今後, 電顕免学絸織化学法に用いられ てよい方法である。ただ，染色結果の判定上，肝実質細 胞や白血球に内在性 Biotin が存在すること飞留意しな ければならなく，現在，有效な阻止方法が開発されてい ないのが現状である。

（4）グルタールアルデヒドによる再固定

抗原抗体反応を終了した後, 10\%ショ糖添加 PBS で 抗原之反応せず, 残存している抗体を十分洗い落し，1\% グルタールアルデヒドで再固定を行う．凍結切片のグル タールと再固定は，PBSで1\%に稀釈したものを用い， $4{ }^{\circ} \mathrm{C} 10$ 分間行っている. 固定後は, 固定液の洗浄を十分 行うことが必要で, これが組織切片内に残存するとペル オキシダーゼの酵素活性の低下ばかりでなく，つぎのス テップの Graham-Karnovsky液による反応を障害する. この操作は, 抗原抗体反応により抗原局在部位に沈着し た標識抗体を，より確実に不動化するとともに組織の固 定を一層確実にするため行うるのである.

細胞質 (cytosol) 飞局在する抗原蛋白（肝細胞内のグ ルタチオンペルオキシダーゼなど）では，再固定を行っ ても，抗原抗体複合物の不動化はまだ十分とはい兄ず， 筆者らは, グルタールアルデヒド再固定の後, $\mathrm{DAB}$ 液
表 1 抗体の大きさと検出可能な抗原の局在部位

\begin{tabular}{|c|c|c|}
\hline & 抗 & 抗原の局在** \\
\hline 1. 直接法 & $\mathrm{Fab}^{\prime}-\mathrm{HRP}$ & $\begin{array}{l}\text { ミトコンドリアを } \\
\text { 含さすべての細胞 } \\
\text { 内小器官 }\end{array}$ \\
\hline 2. 直接法 & $\mathrm{F}\left(\mathrm{ab}^{\prime}\right)_{2}-\mathrm{HRP}$ & $\begin{array}{l}\text { 分泌顆粒, 粗面小 } \\
\text { 胞体 Golgi 装置 }\end{array}$ \\
\hline 3. 直接法 & IgG-HRP & $\begin{array}{l}\text { 細胞膜表面, 細胞 } \\
\text { 膜が破壞された場 } \\
\text { 合のみ, 粗面小胞 } \\
\text { 体など }\end{array}$ \\
\hline 4. 間接法 & $\left\{\begin{array}{l}\text { 一次 : Fab' } \\
\text { 二次 : Fab'-HRP* }\end{array}\right.$ & $\begin{array}{l}\text { ミトュンドリアを } \\
\text { 含むすべての細胞 } \\
\text { 内小器官 }\end{array}$ \\
\hline 5. 間接法 & $\left\{\begin{array}{l}\text { 一次 : } \mathrm{F}\left(\mathrm{ab}^{\prime}\right)_{2} \\
\text { 二次 }: \mathrm{F}\left(\mathrm{ab}^{\prime}\right)_{2}-\mathrm{HRP}^{*}\end{array}\right.$ & $\begin{array}{l}\text { 分泌顆粒, 粗面小 } \\
\text { 胞体, Golgi 装置 }\end{array}$ \\
\hline 6. 間接法 & $\left\{\begin{array}{l}\text { 一次 : } \mathrm{IgG}^{* * *} \\
\text { 二次 }: \mathrm{F}(\mathrm{ab})_{2}-\mathrm{HRP}^{*}\end{array}\right.$ & $\begin{array}{l}\text { 分泌顆粒, 粗面小 } \\
\text { 胞体, Golgi 装置 }\end{array}$ \\
\hline
\end{tabular}

* 一次抗体と同種の動物の $\mathrm{F}\left(\mathrm{ab}^{\prime}\right)_{2}$ をつくり, こ れに対する抗体の $\mathrm{Fab}^{\prime}$ または $\mathrm{F}\left(\mathrm{ab}^{\prime}\right)_{2}$ に HRP を標識した。

** 凍結切片法で, 一次, 二次反応とも 6 12 時間 とした。

*** 浸透性がよくないので, $6 \mu$ 切片, 20 時間以上 の反応時間が望ましい。

に浸漬する前に，つぎのよらな $1 \%$ ゼラチン処理操作を 加えることにより，満足すべき結果を得ている7).

(1) $1 \%$ ゼラチン液/ $0.1 \mathrm{M}$ (リン酸緩衝液) に $2 \sim 3$ 分間浸寸。

(2) ドライヤーで急速に乾燥（加温しない）

(3) $2 \%$ グルタールアルデヒド/PBS で10分間再固定

(4) 冷 PBS で十分洗浄

（5） diaminobenzidine (DAB) による標識酵素の酵 素細胞化学反応

ペルオキダーゼの染色法は光顕の場 合と同様, Graham-Karnovsky 法を用いる. 電顕醭素抗体法の場合は, 基質の $\mathrm{H}_{2} \mathrm{O}_{2}$ を除いた DAB 液 (incomplete GrahamKarnovsky solution) 飞 $1 \%$ dimethylsulfoxide (DM $\mathrm{SO})$ を源加したもので，室温30分反応させた後，洗浄 することなく $\mathrm{H}_{2} \mathrm{O}_{2}$ を加光た DAB 液 (complete-GrahamKarnovsky solution）で $5 \sim 10$ 分間反応させる二段階法 を行っている。

この pre-incubation は, DAB の浸透が $\mathrm{H}_{2} \mathrm{O}_{2}$ より, ながく時間がかかるので, あらかじめ $\mathrm{DAB}$ をく浸み 込ませて打く必要があるためである。

（6）オスミウム酸による後固定

DAB 反応の後組織切片を PBS で洗浄, $0.1 \sim 0.05 \mathrm{M}$ リン酸緩衝液で $2 \%$ に稀釈したオスミウム酸で室温 1 時 間反応させる，その結果，HRP の反応産物が不溶性の DAB となって細胞組織内に沈着した部位にオスミウム 酸が反応して, オスミウムブラックとなり, 電子顕微鏡 
下で観察可能なコントラストが得られるようになる.

（7）脱水, 樹脂包埋

反応の終った組織切片ののったスライドグラスを光顕 用の染色力ゴに入れ，50\%,70\%, 90\%, 95\%, 100\%の工 タノール系列で脱水を行う。脱水時間は, 室温で各ステ ップ 5 分間ずっ， $100 \%$ エタノールは 3 回拈の拈の 10 30 分以上が望屯しい. エタ, 一几脱水後, アセトンや QY-1などの置換剂は省略し，エポキシ樹脂を満たした ゼラチンカプセルを逆さにして，エタノールがまだスラ イドグラスに残っている状態で切片の上にかぶせる。樹 脂の重合比, 重合時間は通常電顕の場合飞準して行う が，やや硬目のほらがよく，筆者らの研究では Quetol 12を使用した場合， $3: 7$ の混合比で， $60^{\circ} \mathrm{C} 2 \sim 3$ 日の 重合時間で薄切可能なブロックを得ている（図1）.

（7）超薄切片作成之電顕観察

重合の終った樹脂ブロックは, ガスバーナーでスライ ドグラスの下面より 10 秒程度加熱することにより，容易 にガラス面よりはがすことができる（図 1)，この操作 により，組織切片は樹脂側に移る。この方法で作製され たブロックは, 図 2 のように光学顥微鏡下で直接観察可 能であり, 厚切り切片作成の必要はない、

䫓微鏡下で目的とする位置にマークをつけ，余分な部 分をグラインダーやヤスリで削り落とし, 実体顕微鏡下 でトリミングを行う。こうして得られたブロックから超 薄切片を作成するが，その基本操作は通常電顕ブロック の場合と同様に行う。

超薄切片は, 必ず無染色のまま電顕観察を行い, 組織 細胞内での反応産物の局在を確認し, その後, 必要に応 じて電子染色を施すことが望ましい. 無染色でもやや厚 目の切片で, 低加速電圧, 絞り径の縮小によりかなり良 好なコントラストが得られるが, 組織細胞の超微構造と 抗原蛋白の局在部位との関連が要求される場合には, ご く短時間鉛染色（Sato の鉛染色法で 30 秒〜 1 分間）を 行っている.

以上の電顕酵素抗体法の手技の概略を解説したが，そ の操作手順を表 2 に示す.

\section{樹脂超薄切片法 ${ }^{3)}$}

凍結切片上で抗原抗体反応を行らかわりに, 電子顕微 鏡用の超薄切片上でそれを行うのが，この樹脂超薄切片 法(pre-embedding method)である. この場合, 凍結融解 による組織破壞や細胞質内物質の流れだしがないので, 超微形態の保存がきわめてすぐれており, かつ, ぞの細 胞内小器官にめる抗原物質も切片上に露出しているため 抗体の浸み込みも問題にならなく, IgGにペルオキシダ 一ゼを標識した抗体を使っても peroxidase antiperoxidase method (PAP 法) を利用した免疫電顕法でも利 用できる。乙かし，樹脂包埋までの課程で抗原性が失活

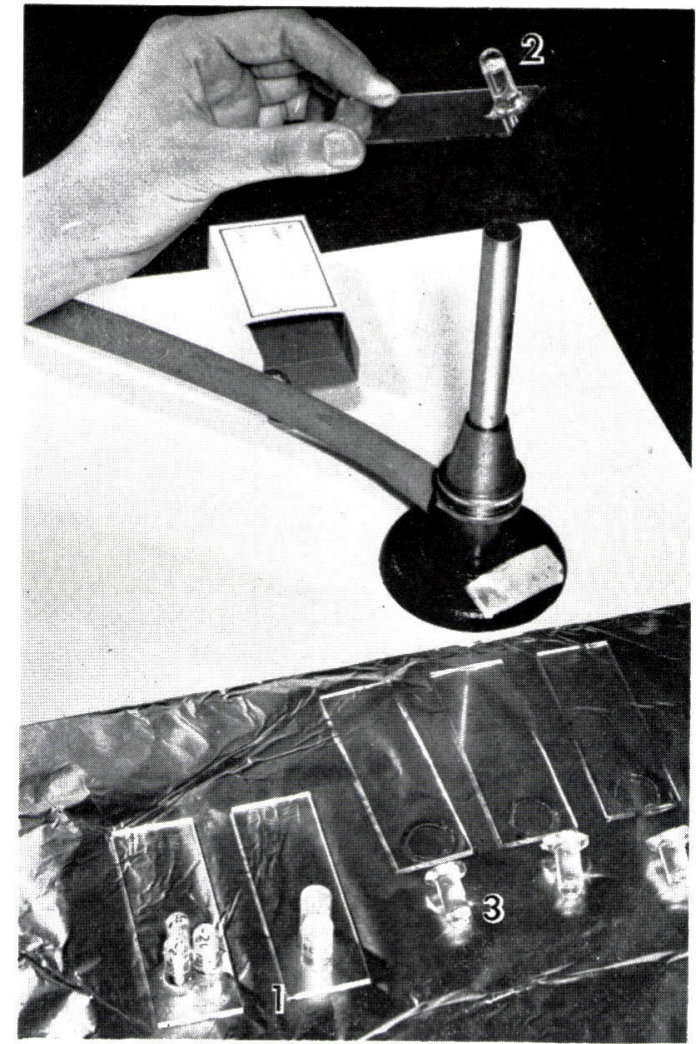

図 1 樹脂の重合の終ったブロック(1)をスライ ドグラスよりガスバーナーの加熱(2)によ つて剥がす

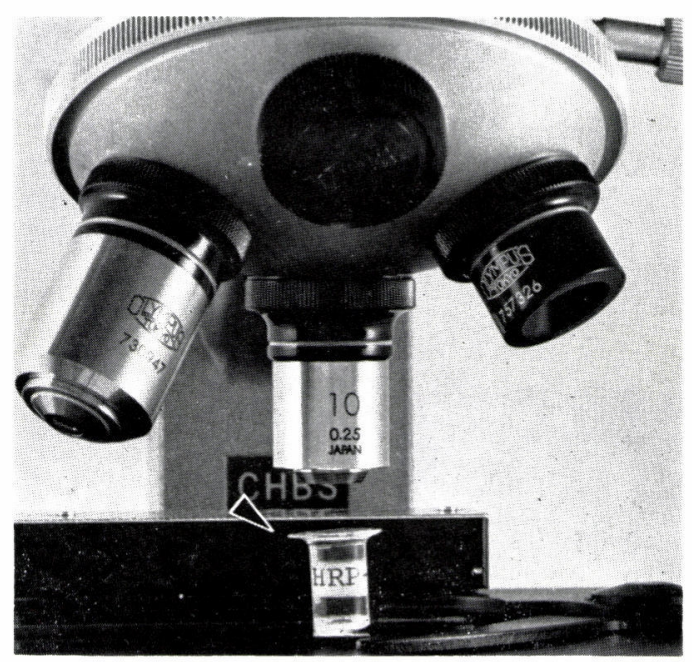

図 2 光学顕微鏡下で樹脂ブロック( の) の観察 が可能である。

されやすく，蛋白性抗原の場合はほとんど用いることが でさず， ペプチドホルモンのように比較的分子の小さい ペプチドの局在観察に適している。超薄切片の作成の操 作は, 通常の電顕用ブロック包埋と注注同様に考えてよ い.また, DAB の浸み込みに問題がないので, 光顕の 
表 2 酵素標識抗体法（直接法, 間接法) に上る 電顕標本作成手技

(1) アルブミン塗布スライドグラスル $6 \sim 12 \mu$ の凍 結切片をのせる。

（2） 30 分間，室温で風乾

(3) 冷 10\% ショ糖加 PBS で 5 分間ずっ 3 回洗浄

（4） 10非感作ヤギ血清（標識抗体が家鬼でっくられ ている場合は家鬼血清）を毛細管ピペットで切 片上にのせ, 温室 (moisture chamber) 中で10 分間室温で反応

(5) 冷 $10 \%$ ショ糖加 PBS で 1 回軽く洗捸

$(6)^{*}$ 一次抗血清 (Fab' または $\mathrm{F}\left(\mathrm{ab}^{\prime}\right)_{2}$ を毛細管ピ ペットで切片の上にのせ, 湿室中で $4^{\circ} \mathrm{C} 6 \sim 18$ 時間反応

(7) *冷 $10 \%$ ショ糖加 PBS で10分間ずっ 5 回以上洗 浄 $(6 \sim 12$ 侍間洗浄が望屯しい)

(8)*同様にペルオキンダーゼ標識二次抗体 (HRP$\mathrm{Fab}^{\prime}$ たは HRP-F $\left(\mathrm{ab}^{\prime}\right)_{2}$ を湿室中で $4 \sim 6$ 時 間反応

(9) 冷 10\%ショ糖加 PBS で10分間ずっ3 回洗浄

(10) 冷 $1 \%$ グルタールアルデヒド（PBS で稀釈）で $4^{\circ} \mathrm{C} 5 \sim 10$ 分間再固定

(11) 冷 PBS（以下の操作からショ糖を加えない）で 5 分ずつ 5 回以上, 十分洗浄

(12) $\mathrm{H}_{2} \mathrm{O}_{2}$ を添加しないDAB 客液 (incomplete Graham-Karnovsky's solution) $k 1 \%$ DMSO を加えたものに30分間, 公温で浸漬

(13) 洗浄することなく DAB- $\mathrm{H}_{2} \mathrm{O}_{2}$ (GrahamKarnorsky's solution) で $5 \sim 10$ 分間反応

(14) 冷 PBS で 5 分間ずっ 3 回洗浄

(15) $2 \% \mathrm{OsO}_{4}$ (リン酸緩衝液で $\mathrm{pH} \mathrm{7.4)で} 1 \sim 2$ 時間, 室温固定

(16) 冷 PBS で洗浄後，型ど打りエタノール脱水， 樹脂包埋

*直接法の場合は,(6)の一次抗体のかわりに(8)のよ 5にペルオキシダーゼ標識抗体 (HRP-Fab' たは HRP-F $\left.\left(\mathrm{ab}^{\prime}\right)_{2}\right)$ を反応させ，(9)以下の操作 にすすを。

場合と同様 $\mathrm{DAB}$ 反応は 1 ステップでよい. 酵素抗体間 接法による操作の手順は表 3 に示すとおりである.

\section{培養細胞の電顕酵素抗体法}

培養細胞系を使った免疫電顕法はウイルス学の領域 で, 主としてフェリチン抗体法を用いて行われてきた。 しかし細胞質内への標識抗体の浸透が，その細胞を蛋白 分解酵素や界面活性剂で破壊しないかぎり，ほとんど期 待できないフェリチン抗体法では, ウイルス蛋白の細胞 内局在を厳密に観察することはきわめて困難といわざる をえない，その点，いままで紹介してきた電顕酵素抗体 法は, 培養細胞系を用いたウイルス感染細胞の免疫組織 化学的研究にもっともすぐれた手技の一つであろう（図 $9)^{8)}$ 。また，このことは培養細胞系での肝細胞や形質細 胞, あるいは種々の腫瘍細胞の蛋白合成, ならびに運搬 の機構の解明に, 従来行われてきた電顕オートラジオグ ラフィ法に加え, 電顥酵素抗体法の導入が期待される所
表 3 樹脂超薄切片法の操作手順

(1) 型どおり固定, 樹脂包埋超

（2）薄切片作製，ニッケルグリッドにのせる.

（3） $10 \%$ 過酸化水素水で10分間, 室温で処理

(4) $1 \%$ BSA 添加 PBS で洗浄

(5) 湿室内でパラフィルム上に一次抗血清を 1 滴滴 下，その上にグリッドを浮遊させ，30分間反応

(6) $1 \%$ BSA 添加 PBS で洗哖

(7) (5)と同じ要領でペルオキダーゼ標識二次抗体をと 反応

(8) $1 \% \mathrm{BSA}$ 添加 PBS で洗浄

(9) $\mathrm{DAB}-\mathrm{H}_{2} \mathrm{O}_{2}$ 液*で反応

(10) $1 \%$ BSA 添加 PBS で洗浄

(11) $2 \%$ オスミウム酸で後固定

(12) 十分洗浄の後切片を乾燥, 鏡検

* 光顕の場合と同様 $20 \mathrm{mg} \mathrm{DAB} / 100 \mathrm{ml} / \mathrm{H}_{2} \mathrm{O}+$ $0.05 \% \mathrm{H}_{2} \mathrm{O}_{2}$

以である。

培養細胞の免疫化学組織的観察は, 普通,

1. 単層培養細胞 (monolayer) を PLP で固定の後, ラバースクレーパ (rubber scraper) で掻き集めたもの， あるいは浮遊培養細胞の固定したものを遠沈してペレッ トをつくり，これを part I で述べた手順に従って， OCT compound 飞包埋，凍結切片を作成する方法 ${ }^{9)}$

(2) dish slide (Lab Tek-三光純薬)，またはカバー グラス（培湌びん中に静置された短ざく型のカバーグラ ス）上に単層培養されたものをそのまま固定, 洗浄を行 い, 酵素抗体染色を施す方法が行われている。

Iの場合は, 以下の操作も本稿の凍結切片法の手技に 準じて行らことができるが，(2)のごとく dish slide 上の 単層培養細胞に直接標識抗体を反応させる場合, その細 胞内浸透がきわめてわるく, 原則として特異抗体は $\mathrm{Fab}^{\prime}$ しか用いることができなく，反応時間も12時間以上必要 になる。それでも，なお標識抗体の浸透が十分でない場 合, dish slide の裏面（細胞が付着していない側）より フレオンガスを噴霧して急速に冷凍，融解することによ り，良好な浸透性を得ている。この場合，凍結融解によ る微細構造の破壊を防ぐため, あらかじめ凍結切片作成 の場合と同様に， dish slide にのった培養細胞を10\%シ : 糖加 PBS, 15\% シ 糖加 PBS, 20\% シ 糖加 PBS で 十分浸漬の後凍結融解操作をすることが望ましい，抗原 抗体反応後は型どおり, グルタール固定, DAB 反応, オスミウム酸後固定, アルコール脱水を経て, 樹脂を満 たしたゼラチンカプセルを直接 monolayerの上に逆さに かぶせ重合させる（表 4).

電顕酵素抗体法と電顕酵素組織化学法との重染色 ${ }^{10)}$

電影酵素抗体法の場合, 究極的にはペルオキシダーゼ 
表 4 培養細胞の電顕酵素抗体法による観察法 の操作手順

（1）単層培養の場合, 培養器より培養液を捨て, 冷 PBS で 3 回洗浄, 浮遊培美細胞の場合は800 900rpmで 5 〜 10分間軽く遠沈，培養液を袑て, 同様に 3 回冷 PBS で洗浄

（2） PLPを培養器中に加光， $4^{\circ} \mathrm{C}$ で 30 分〜 1 時間固 定

（3）単層培養の場合は, 固定液中で rubber scraper で細胞をかきとり，その細胞浮遊液をプラスチ ック遠沈管中で遠沈，固定液を捨てる。

(4) $10 \%$ シ 糖加 PBS 中に浮遊させる.

(5) 1, 000 1, $200 \mathrm{rpm}$ で遠沈，上清を捨て，再度 $10 \%$ シ 糖加 PBS 中に浮遊させ， 2 時間 $4^{\circ} \mathrm{C}$ で静置

(6) 以下(5)と同様に, $15 \%$ ショ糖加 PBS, $20 \%$ ショ 糖加 PBS, $5 \%$ グリ七リン添加 $20 \%$ ショ糖加 PBS 中で浮遊遠沈を繰り返えす。

(7) 2000rpmで遠沈，上清を捨て，ペレットの上に OCT-compound を静かに重畳する。

（8）スパーテルを遠沈管壁とペレットの間にさしこ み, OCT-compound をぺレットの中に浸み込 ませる。

（9）ドライアイスエタノール中に遠沈管を入れ迅速 に凍結を行 5 .

(10) 遠沈管をハンマーで壊し， OCT-compound 中 に凍結されたペレットをとりだす。

(11) 凍結された OCT-compound を適当な長さに切 断し,アルミホイルでつくった包埋容器中に入 れ, 周囲に OCT-compound を満たし再凍結

(12) 凍結切片を型どおり作成

の酵素組織化学的検出法に依存しているわけであるか ら, 他の酵素組織化学との重染色が理論的に可能であ る、筆者らは, 免疫グロブリンや secretory component とアルカリフォスファターゼや, 酸フォスファターゼを それぞれ電顕酵素抗体法と Tranzer の金属塩法，また は Novikoff 法により，電顕レベルで同一切片上での観 察に成功している。すなわち, 超微形態レベルでの抗原 蛋白の局在と酵素活性を同時に観察することを可能にし た（図 7 ).

酵素抗体法単独の場合と同様の手順で，PLPで固定さ れた組織について, 凍結切片法で酵素抗体染色を行い, 緩衝液で十分洗浄の後, 酵素活性染色を施し, 引きつつ き二段階の DAB 反応を行っている. 表 5 はその操作手 順である。

\section{細胞膜表面抗原やレセプターの電顕酵素抗体法}

リンハ球, マクロファージ, あるいは種々の腫瘍細胞 の細胞膜抗原の識別, 拈よび種々の受容体 (receptor)の 検出を, その細胞の微細構造観察之同時に行うことは, ながい間免疫学や内分泌学領域の夢であった。

玉置らは, マゥス脾蔵, リンパ節, 胸腺あるいは胎児 肝を用い, それらを緩衝液中で遊離細胞とし, 未固定の まま Nakane の酵素抗体間接法に準じ， $4^{\circ} \mathrm{C}$ で抗原抗体
表 5 電顕酵素抗体法と酵素組織化学々の重染 色法
(1) 凍結切片を冷 $10 \%$ シ 糖加 PBS で洗浄

(2) 標識抗体で室温, $3 \sim 5$ 時間反応

(3) 冷 10 シ 糖加 PBS で十分洗浄

(4) $1 \%$ ルタールアルデヒド (in PBS) で $4{ }^{\circ} \mathrm{C}$ 10分間固定

(5) 冷 PBS（このステョプよりショ糖は加えなくて bよい)

(6) 冷 tris-maleate buffer (0.1 M, pH 7.4) で 3 回，計 $30 \sim 60$ 分間洗浄

（7）アルカリフォスファターゼ反応 (Tranzer 法), 室温, $5 \sim 15$ 分間

(8) 冷 tris- $\mathrm{HCl}$ buffer (0.05M, pH 7.6) で 3 回, 計 $30 \sim 60$ 分間洗浄

（9）二段階の DAB 反応の後，オスミウム酸固定， 脱水, 樹脂包埋

表 6 細胞膜抗原の電顕酵素抗体法による観察 手技

(1)* 遊離細胞（組織の場合，5\% fetal calf serum 添加 PBS 中で汪ぐして遊離細胞とする）を冷 PBS (pH 7.2) で十分洗浄

$(2)^{*}$,** 試験管内で，第一抗体 $\left(\mathrm{Fab}^{\prime}\right.$ 屯たは $\mathrm{F}\left(\mathrm{ab}^{\prime}\right)$ を細胞 $1 \times 10^{7}$ 個に対して $0.1 \mathrm{ml}$ 添加, $4^{\circ} \mathrm{C} 30$ 分 間反応

(3)* 冷 PBS で 3 回洗浄

(4)*ペルキシダーゼ標識第二抗体 (HRP-Fab'また は HRP-F $\left.\left(\mathrm{ab}^{\prime}\right)_{2}\right)$ と $4^{\circ} \mathrm{C} 30$ 分間反応

(5)* 冷 PBS で 3 回洗浄

(6) $2 \%$ グルタールアルデヒドで $4^{\circ} \mathrm{C} 20$ 分間固定

(7) 冷 PBS で 3 回洗浄

(8) $\mathrm{H}_{2} \mathrm{O}_{2}$ 添加 $\mathrm{DAB}$ 溶液で室温 5 分間反応

(9) 冷 PBS で洗浄

(10) 試料を試験管から電顕用ビームカプセルに移 し，2\%オスミウム酸（リン酸緩衝液で $\mathrm{pH}$ 7.4) で 1 時間室温固定.

(11) PBS 洗浄, 脱水, エポン包埋

* アジ化ナトリウムを添加してもよい.

** fisher tube 管を使用するとよい。

反応を行った後, グルタールアルデヒドで固定, DAB 反応を行うことにより, 種々の細胞膜抗原の検出に満足 すべき結果を得ている11)

この際, 留意すべき点は, 生細胞で抗原抗体反応を行 らため, Fcレセプターとの非特異結合の防止や, capping の阻止であり，そのために抗体との反応は，0〜 ${ }^{\circ} \mathrm{C}$ で 行うとともに，抗体には $\mathrm{Fab}^{\prime}$ もくは $\left(\mathrm{Fab}^{\prime}\right)_{2}$ を用いる ことが肝要であり, 必要に応じて反応洗浄の各ステップ にアジ化ナトリウムを添加している.

筆者らも，この方法を応用し， B 細胞系の表面免疫グ ロブリン (surface immunoglobulin) や, リンパ球表面 の HLA の検出に成功している，また前項で述べた酵素 組織化学との重染色も同様に可能である。表 6 は，その 


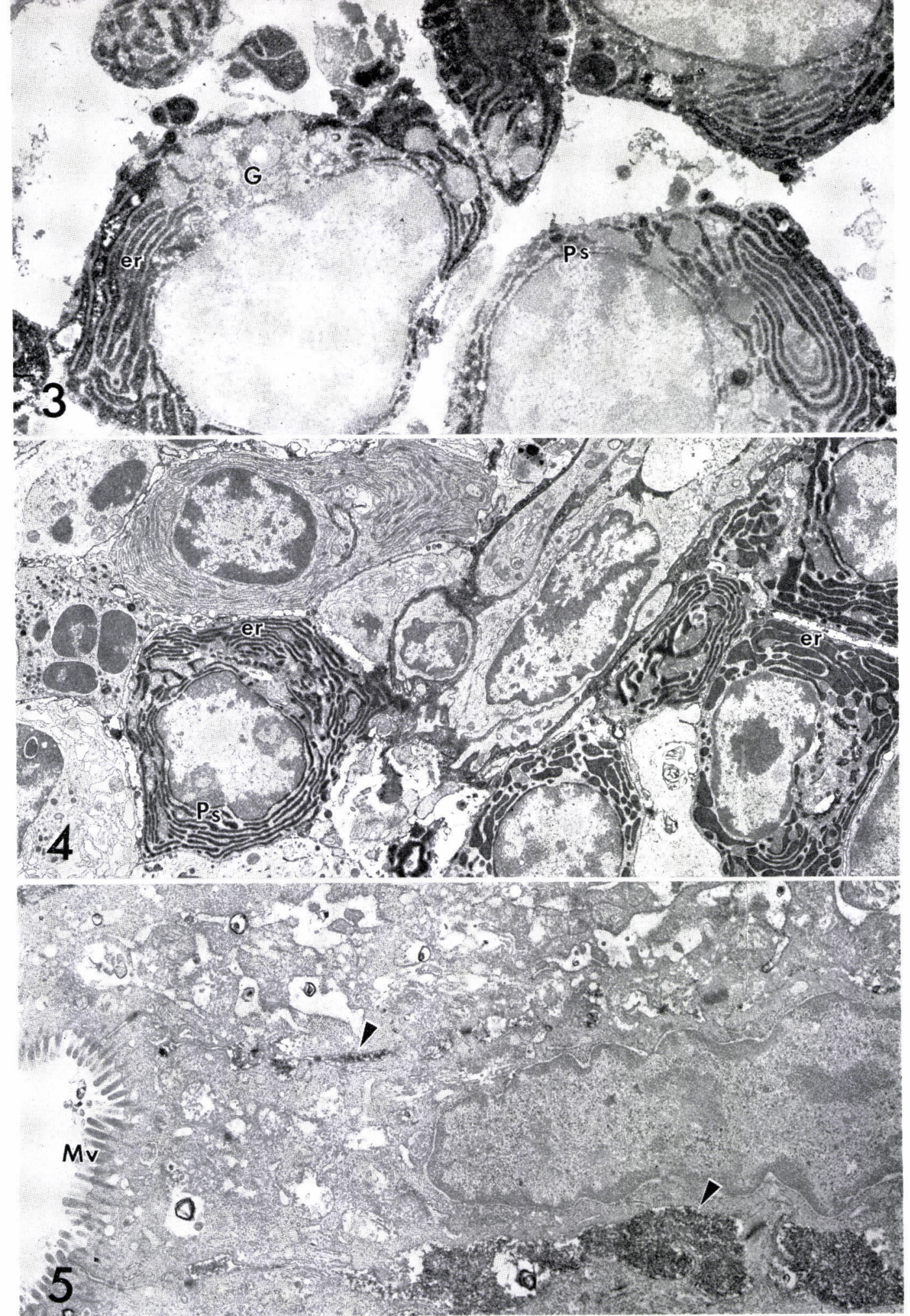

図了䉓顕酵素抗体法による免疫グロブリン産生細胞（IgA) の钼察

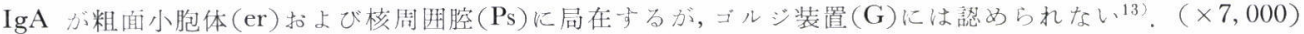

図 4 醅䒺抗原法による免疫グロブリン産生細胞の観察

抗 HRP 抗体が形質細胞の粗面小胞体 (er) 扣よび核周囲腔 (Ps) 飞染色される ${ }^{13)}$. $(\times 5,000)$

図 5 proteiloosing syndrome 患者十二指腸の生検組織

$\operatorname{IgA}$ が腸管上皮細胞間隙に眝留されている（），( × 10,000） 


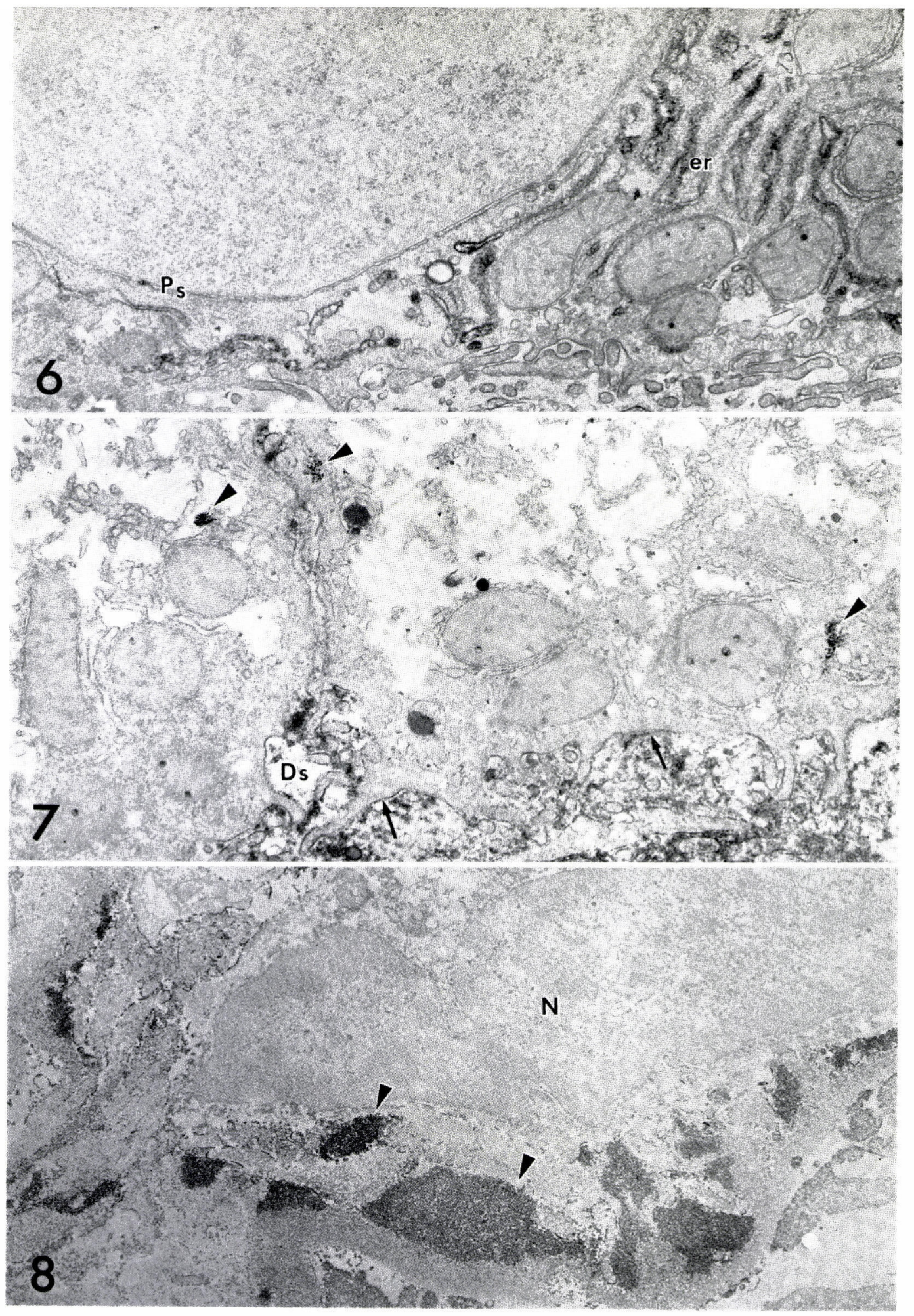

図 6 肝細胞に打ける補体 $\left(\mathrm{C}_{4}\right)$ の局在

補体は粗面小胞体 (er) おょび核周囲腔 (Ps) に惩められ，肝細胞で産生されることが証明された15).

$(\times 17,000)$

図 7 肝臓に扣ける IgA 蛋白と酸フォスファタ一七゙活性の重染色

$\operatorname{IgA}$ は, 肝細胞の類洞扣よびディッ七腔 (Ds) に面した細胞膜表面( ( 細胞内に取り込末れた（IgA）は，酸フォファターゼとともに染色され（一），細胞内消化を受ける ことが示唆された16) $(\times 20,000)$

図 8 腎生㭘組織（IgA 腎症）の IgA 染色

PLP 固定後, 型ど扣り電顕酵素抗体法で観察した。IgA はィサンギウム細胞 (N) 周囲の matrix に認められる 


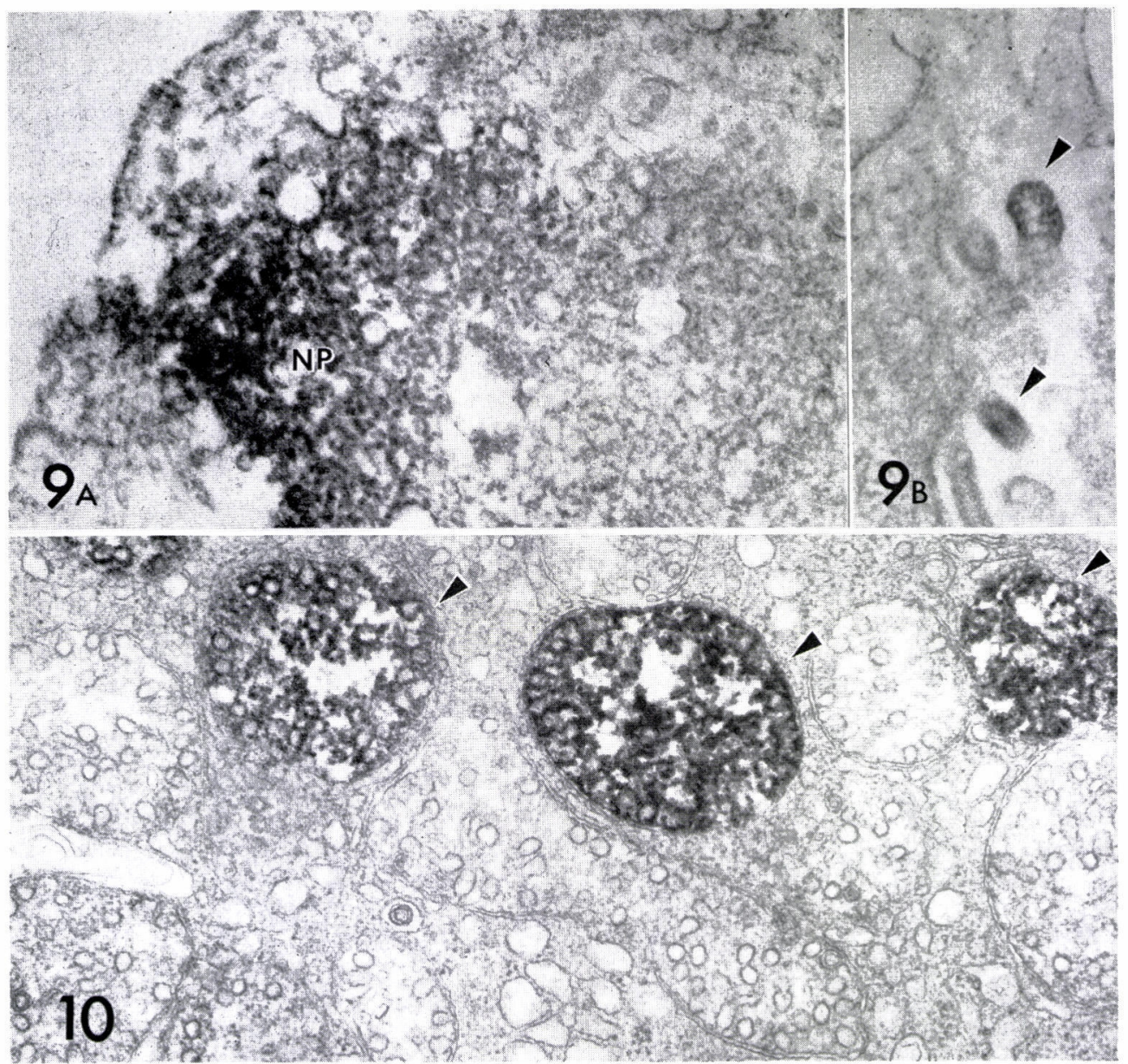

図 9 BHK 培湌細胞に扣ける newcastle disease virus (NDV)の NP 蛋白の局在

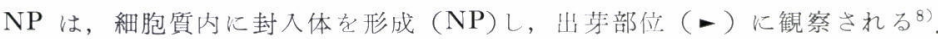

$(\mathrm{A}: \times 20,000, \mathrm{~B}: \times 30,000)$

図 10 正常ラット副腎皮質細胞内の adrenodoxin reductase のミトコンドリア局在 $(\text { 一 })^{4}$

$(\times 30,000)$ (東海大病理, 渡辺慶一教授提供)

表 7酵素抗原法による抗体库生細胞観察の手技
（1） HRP で動物を免疫し血清抗体価が十分亦がの た後，目的のリンパ節などを採取
(8) $1 \%$ グルタールアルデヒド (0.1M リン酸緩衝 液, $\mathrm{pH} 7.4)$ で $4^{\circ} \mathrm{C} 10$ 分間後固定
(2)* PLPなたは $4 \%$ パラホルムアルデレド $(0.1 \mathrm{M}$
(9) PBS で 3 回，30分間洗浄
リン酸緩衝液, $\mathrm{pH} 7.4)$ で $4^{\circ} \mathrm{C} 3$ 時間固定
(10) $\mathrm{H}_{2} \mathrm{O}_{2}$ 添加したい $1 \%$ DMSO 添加 DAB 溶液 (incomplete Graham-Karnovsky 溶液) で室 温，30分間反応
(3)* 洗浄することなく $1 \%$ グルタールアルデとド 1 時固定
(11) 洗浄するこ子なく $\mathrm{H}_{2} \mathrm{O}_{2}$ 添加 Graham-Kar- novsky 溶液で 5 〜 10 分間室温で反応
(4)* 冷 PBS で洗浄, 3 回交換 $4^{\circ} \mathrm{C} 12$ 時間 1 夜
(5)* 組織切片（マイクロチョッパーなど） $20 〜 40 \mu$ 作成
(12) PBS で 3 回30分間洗浄
$(6)^{* *} 10 \sim 20 \mu \mathrm{g} \mathrm{HRP} / \mathrm{ml} / \mathrm{PBS}$ に浸漬, $4^{\circ} \mathrm{C} 6 \sim 12$ 時間
(13) $2 \%$ オスミウム酸 $(0.1 \mathrm{M}$ リン酸緩衝液で室温 1 時間固定)
(7) 冷 PBS で 3 回30分間洗浄
(14) 型ど扣り脱水, 樹脂包埋

*凍結切片法の場合グルタールアルデヒド固定を行うことなく，型ど扣り $10 \%, 15 \%, 20 \%$ ショ糖加 PBS で洗浄 後, グリセリン処理, OCT-compound に包埋, 凍結切片を作成する (part I 表 1 参照)。この場合にはPLP, パラホルムアルデヒド固定は 6 時ぐらいが望ましい。

**凍結切片法の場合 $2 \sim 3$ 時間で十分である。 
操作手順の概略を示したが，詳細は玉置らの著書を参考 にされたい.

\section{走査型免疫電顕法}

以上述べてきた電䫓酵素抗体法は，すべて透過型電顕 を用いた観察法であるが, 最近, Nakane \& Hartmanに より走査型電顕による電顕酵素抗体法が紹介された ${ }^{12)}$. これは, 酵素抗体法による染色を施した $6 \mu$ 凍結切片を 超薄切片にすることなく, そのまま走査型電顕による観 察を可能にした画期的な万法で, 今後, 日常の病理組織 検索や, 免疫学領域での種々の膜抗原の検出などに飛躍 的な発展をとげるものと思われる。 その原理の概略は, backscattered electron imaging を利用し, 酵素抗体法 によって染色された抗原蛋白の局在を検出する方法で, ペルオキシダーゼ標識抗体の局在部位に沈着したところ の DAB のポリマーに結合したオスミウム酸に対する反 射電子 (backscattered electron) を detector で検出す るわけである。詳細は, Nakane \& Hartman の原著を 参照されたい.

\section{酵素抗原法による抗体産生細胞の観察法 ${ }^{13)}$}

抗体産生細胞内に打洔異抗体の局在観察は, いま まで紹介してきた電顕酵素抗体法による局在 観察のほ か, 酵素抗原法が用いられている。すなわち, 外来酵 素, たとえば, 植物性ペルオキシダーゼ (HRP) あるいは E. coli のアルカリフォスファターゼ (ALP) を抗原とし て動物を免疫し, 抗 HRP あるいは抗 ALP を産生して いる抗体産生細胞を含むりンパ組織を抗原である酵素液 に浸漬させ, その結果, 抗体局在部位に沈着した抗原酵 素の局在を酵素組織化学的に検出する方法である. 現在 では，主として HRP が抗原として用いられている。

本法では, ある特定の抗原 (この場合は HRP) に対 する特異抗体蛋白を産生する抗体産生細胞のみを特異的 に染めだすことが可能であり（図 4)，この HRP が普 通接種された動物にとってまったくはじめての抗原であ る場合, 抗体産生のごく初期像から観察できる利点があ り, 無菌動物などを使った免疫反応の研究にも匹敵する 研究手段になりらる。この点は, 他の免度組織化学では なしえなく, 感染, 免疫学の研究にもっと利用されてよ い方法と考えている. その操作手順は表 7 亿示すが, 詳 細は筆者らの著書を参照されたい.

\section{おわりに}

以上, 電顕酵素抗体法を中心とした染色手技の実際 と, その留意すべき点の概略を筆者らの経験 ${ }^{14)}$ およびそ れぞれの分野の専門家の業績から紹介するとともに，染 色例を供覧した（図 $3 \sim 10 ）$ ．本稿の枚数の関係で十分 述べきれなかった点は，それぞれの原著，著書を参照さ
れたい. 最後に, この酵素標識抗体法が炎症, 免疫領域 の研究にもっとも利用されることを切望している. (part I の図 2 と図 3 が逆になっていますので訂正いたしま †).

渡边慶一教授ならびに Paul K. Nakane 教授のご指 導に深謝いたし尔す。

\section{文 献}

1) McLean, I.W., Nakane, P.K.: Periodate-lysineparaformaldehyde fixative: a new fixative for immunoelectron microscopy. J. Histochem. Cytochem. 22: 1077-1083, 1974.

2) Tokuyasu, K.T.: A technique for ultracryotomy of cell suspensions and tissues. J. Cell Biol. 57: 551-565, 1973.

3) 長村義之：電顕酵素抗体法の細胞生物学・病理学 への応用。細胞 11：230-243，1979.

4) Mitani, F., Ishimura, Y., Izumi, S., Watanabe, $\mathrm{K}$.: Immunohistochemical loclization of adrenotoxin and adrenodoxin reductase in bovine adrenal cortex. Acta Endoclinol. 90: 317-327, 1979.

5) Nagura, H., Brandtzaeg, P., Nakane, P.K., Brown, W.P.: Ultrastructural localization of $\mathrm{J}$ chain in human intestinal mucosa. J. Immunol. 123: 1044-1050, 1979.

6) Guesdon, J., Ternynck, T., Avrameas, S.: The use of Avidin-Biotin interaction in immunoenzymatic techniques. J. Histochem. Cytochem. 27: 1131-1139, 1979.

7) 小松遵至：ラット肝 Glutathione Peroxidase (GSH-PO) 局在の電顕酵素抗体法による観察. 細胞 11: 209, 1979.

8) Nagai, Y., Yoshida, T., Hamaguchi, M., Nagura, H., Hasegawa, H., Yoshimura, S., Watanabe, K.: Morphogenesis of paramixoviruses: Localization of the structural proteins of Newcastle disease virus and Sendai virus to subcellular or ganellas of infected cells by ultrastructural immunocytochemistry. (submitted.)

9) Nagura, H., Nakane, P.K., Brown, W.R.: Translocation of dimeric IgA through neoplastic colon cells in vitro. J. Immunol. 123: 2359-2368, 1979.

10）長谷川英章，名倉 宏，渡辺慶一，生越喬二, 三 富利夫：胃粘膜化生上皮細胞の免疫組織化学々酵 素組織化学. 消化器と免疫 Vol. 5. 医歯薬出版, 1980, p 64-70.

11）玉置憲一，垣生園子： $\mathrm{T}$ 細胞の抗原分化々超微形 態。新版日本血液学全書 (9), 丸善, 1981, p 116.

12) Nakane, P.K., Hartman, A.L.: Immunocytochemical localization of intracellular antigens with SEM. (in press)

13）渡辺慶一, 名合 宏: 抗体産生像の超微形態. 新 版日本血液学全書( 9 ), 丸善, 1981, p 197-220. 
14）渡辺慶一(編)：酵素抗体法一理論・手技解説とそ の応用一。学際企画, 1981.

15）名倉 宏, 渡辺慶一, 長谷川英章, 吉村真一, 杉 本栄一：ヒ卜生梗肝に扣ける補体 $\left(\mathrm{C}_{3}, \mathrm{C}_{4}\right)$ の局 在とその病理学的意義。消化器と免疫 Vol. 7, 医䔉薬出版，1981，p 87-92.

16）名倉 宏, 長谷川英章, 堤寛, 小林邦彦, 渡 辺慶一：ヒ卜肝生検組織に扣汀る $\operatorname{IgA}$ の局在とそ
の病理学的意義. 消化器々免疫 No. 8, 医菌薬出 版, 1982, (印刷中).

17) Komatsu, N., Nagura, H., Watanabe, K., Nomoto, Y., Kobayashi, K.: Immunocytochemical evidence for mesangial deposits of $\mathrm{J}$ chain-linked polymeric IgA in IgA nephropathy. (submitted). 